\title{
The Effects of Caffeine on the Preterm Sheep Ductus Arteriosus
}

\author{
RONALD I. CLYMAN AND CHRISTINE ROMAN
}

\author{
Cardiovascular Research Institute and Department of Pediatrics, University of California San Francisco, San Francisco, California 94143
}

\begin{abstract}
Caffeine and other methyl xanthines are widely used in the neonatal period. A recent, randomized, placebo-controlled, multicenter trial found that infants who were randomly assigned to caffeine treatment had less need for pharmacologic and/or surgical closure of a patent ductus arteriosus (PDA). We hypothesized that the decreased need for pharmacologic and surgical closure of the PDA after caffeine treatment might be due to a direct effect of caffeine on ductus contractility. We examined preterm fetal lamb ductus arteriosus (from 24 fetuses, $105 \pm 4 \mathrm{~d}$ of gestation, term $=147 \mathrm{~d}$ ), in vitro to determine the direct effects of caffeine on the isometric tension of the ductus arteriosus. Caffeine $(0.003-0.3 \mathrm{mM})$ had no direct effect on ductus arteriosus tension, nor did it affect the contractile response of the ductus arteriosus to increasing oxygen concentrations. Caffeine's lack of effect was observed in both the presence and absence of indomethacin and $\mathrm{N}^{\mathrm{g}}$-nitro-L-arginine methyl ester (L-NAME) (inhibitors of prostaglandin and nitric oxide production). In conclusion, we found no evidence of a direct effect of therapeutic caffeine concentrations on ductus contractility. (Pediatr Res 62: 167-169, 2007)
\end{abstract}

$\mathrm{P}$ emature infants have an increased incidence of PDA after birth. Although in vitro studies have shown that ductus arteriosus patency may be affected by local concentrations of oxygen, prostaglandins, nitric oxide, endothelin, cyclic adenosine monophosphate (cAMP), cyclic guanosine monophosphate, adenosine, and intracellular potassium and calcium ions $\left(\mathrm{K}^{+}\right.$and $\left.\mathrm{Ca}^{2+}\right)(1-10)$, in vivo studies suggest that postnatal constriction is primarily determined by a shift in the balance between oxygen (a ductus constrictor) and prostaglandins and nitric oxide (ductus dilators) $(11,12)$. Alterations in antenatal glucocorticoid concentrations and postnatal pulmonary vascular resistance also play roles in in vivo ductus constriction $(13,14)$.

Recently, a randomized, placebo-controlled, multicenter trial was performed to evaluate the effects of caffeine administration in preterm infants (15). Infants were enrolled in the trial during the first $10 \mathrm{~d}$ after birth, and the primary goal of the study was to evaluate the long-term effects of caffeine on neurodevelopmental outcome. An unexpected finding of the study was that infants who were randomly assigned to caffeine

Received January 11, 2007; accepted March 10, 2007.

Correspondence: Ronald I. Clyman, M.D., University of California, Box 0544, HSW 1408, 513 Parnassus Avenue, San Francisco, CA 94143-0544; e-mail: clymanr@peds. ucsf.edu

Supported by grants from U.S. Public Health Service (NIH grants HL46691 and HL56061) and by a gift from the Jamie and Bobby Gates Foundation. treatment had less need for pharmacologic and/or surgical closure of a PDA.

Caffeine has been found to directly affect several of the signaling molecules that are involved in ductus constriction: it increases cAMP by inhibiting cyclic nucleotide phosphodiesterase (16); it releases $\mathrm{Ca}^{2+}$ from the endoplasmic reticulum by binding to the ryanodine receptor (17); it inhibits both prostaglandin production (18) and activity (19) and inhibits adenosine activity by binding to its receptors (20). At therapeutic concentrations, caffeine's effects appear to be due primarily to antagonism of the adenosine receptor (21).

In this study, we hypothesized that the decreased need for pharmacologic and surgical closure of the PDA after caffeine treatment might be due to a direct effect of caffeine on ductus contractility. To examine this hypothesis, we studied the effects of caffeine on the isolated preterm fetal sheep ductus arteriosus.

\section{METHODS}

Preterm fetal lambs (mixed Western breed: $105 \pm 4 \mathrm{~d}$ of gestation, term $=$ 147) were delivered by cesarean section and anesthetized with ketamine $\mathrm{HCl}$ (30 mg/kg i.v.) before rapid exsanguination. These procedures were approved by the Committee on Animal Research at the University of California, San Francisco.

After dissection, the ductus arteriosus was divided into 1-mm thick rings that were placed into $10-\mathrm{mL}$ organ baths in a dark room as described previously (22). The rings were suspended between two stainless steel hooks at $38^{\circ} \mathrm{C}$ in a modified Krebs solution (in mM; $118 \mathrm{NaCl}, 4.7 \mathrm{KCl}, 2.5 \mathrm{CaCl}_{2}$, $0.9 \mathrm{MgSO}_{4}, 1 \mathrm{KH}_{2} \mathrm{PO}_{4}, 11.1$ glucose, $23 \mathrm{NaHCO}_{3}(\mathrm{pH} 7.4)$ ) and equilibrated with $5 \% \quad \mathrm{CO}_{2}-15 \% \quad \mathrm{O}_{2}$-balance $\mathrm{N}_{2}$. An oxygen electrode (YSI Model 53 Biologic Oxygen Monitor, Yellow Springs, OH), placed in the 10-mL organ bath, measured oxygen concentrations. The bath solution was changed every $20 \mathrm{~min}$. Isometric responses of circumferential tension were measured by Grass FT03C force transducers (Quincy, MA). Each of the rings was stretched to an initial length $(4.9 \pm 0.2 \mathrm{~mm})$ that resulted in a maximal contractile response to increases in oxygen tension (23). After the rings reached a steady-state tension (approximately $100-120 \mathrm{~min}$ ), potassium $\left(\mathrm{K}^{+}\right)$-Krebs solution (containing $100 \mathrm{mM} \mathrm{KCl}$ substituted for an equimolar amount of $\mathrm{NaCl}$ ), equilibrated with $95 \% \mathrm{O}_{2} / 5 \% \mathrm{CO}_{2}$ ), was used to measure the maximal contraction that could be developed by the ductus (maximal contraction). After returning the rings to the initial modified Krebs solution, equilibrated with $15 \% \mathrm{O}_{2} / 5 \% \mathrm{CO}_{2}$, the rings were exposed to one of several experimental protocols: (a) In some experiments, cumulative dose-response curves for caffeine $(0.003-0.3 \mathrm{mM})$ were constructed in $15 \% \quad \mathrm{O}_{2} / 5 \% \quad \mathrm{CO}_{2}$. In some experiments, the maximal caffeine dose was increased to $20 \mathrm{mM}$. (b) In some experiments, a cumulative dose-response curve for caffeine was performed after the tissue had been equilibrated $(1.5 \mathrm{~h})$ with either indomethacin $(0.005$ $\mathrm{mM}$ ) and/or $\mathrm{N}^{\mathrm{g}}$-nitro-L-arginine methyl ester (L-NAME, $0.1 \mathrm{mM}$ ) [concentrations that cause maximal inhibition of prostaglandin and nitric oxide production in the ductus $(9,24)]$. (c) In some experiments, rings were sequentially exposed to an oxygen dose-response curve $(2 \%, 6 \%, 15 \%, 30 \%$, and

Abbreviations: $\mathrm{Ca}^{2+}$, calcium ions; $\mathrm{K}^{+}$, potassium ions; $\mathbf{L}-\mathbf{N A M E}$, $\mathrm{N}^{\mathrm{g}}$-nitroL-arginine methyl ester; PDA, patent ductus arteriosus; SNP, sodium nitroprusside 
$95 \%$ oxygen); after returning to $15 \% \mathrm{O}_{2} / 5 \% \mathrm{CO}_{2}$, the rings were treated with caffeine and then exposed to the same oxygen dose-response curve again. We have previously shown that ductus rings have the same sensitivity and contractile behavior to oxygen when exposed to repeated oxygen doseresponse curves (11).

In all experiments, we allowed the tension in the rings to reach a new steady-state plateau after addition of a drug and before another concentration or experimental agent was added to the bath. Sodium nitroprusside (SNP, 0.1 $\mathrm{mM}$ ) was added to each ring at the end of the experiment to determine its minimal tension.

The difference in tensions between any measured steady-state tension and the minimal tension produced by SNP was considered the net active tension. The difference in tensions between the maximal tension [produced by $\left(\mathrm{K}^{+}\right)$Krebs] and the minimal tension (with SNP) was treated as the maximal active tension capable of being developed by the rings.

Tensions are expressed as a percentage of the maximal active tension. Maximal active tensions were $16 \pm 4 \mathrm{~g}(n=10$ fetuses $)$ in rings exposed to indomethacin and L-NAME and $12 \pm 2 \mathrm{~g}(n=14$ fetuses $)$ in rings not exposed to indomethacin or L-NAME. After the experiment, the tissues were removed from the baths and blotted dry and their wet weights determined (29 $\pm 7 \mathrm{mg}, n=24$ fetuses). Chemicals were from Sigma Chemical Co. (St. Louis, MO).

Statistical analyses. Statistical analyses of unpaired and paired data were performed by the appropriate $t$ test and by analysis of variance. Scheffé's test was used for post hoc analysis. Values are expressed as mean \pm SD. Drug doses refer to their final molar concentration in the bath.

\section{RESULTS}

Because the primary determinant of ductus constriction in vivo is the balance between oxygen concentration and local production of prostaglandins and nitric oxide $(11,12)$, we examined the direct effects of caffeine on ductus arteriosus contractility at different oxygen concentrations and at different rates of prostaglandin and nitric oxide production. As has been observed previously (11), the preterm ductus developed increased tone when exposed to either increasing oxygen concentrations or to indomethacin and L-NAME (Figs. 1 and 2). In contrast, the preterm ductus was not affected by caffeine at concentrations that are normally achieved in vivo $(<0.02 \mathrm{mM})$ (21) or at higher concentrations (up to $0.3 \mathrm{mM}$ ) (Fig. 1).

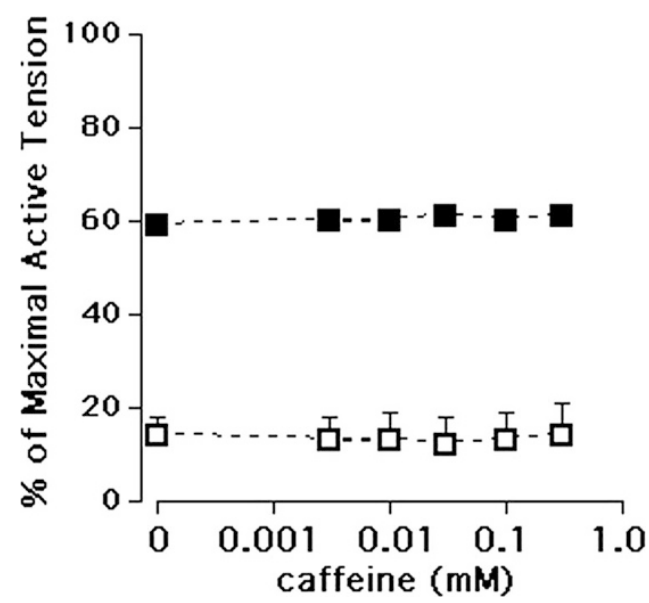

Figure 1. Vasomotor response of fetal ductus to caffeine. Ductus rings were precontracted with $15 \%$ oxygen: rings from five fetuses were studied in the presence of indomethacin $(0.005 \mathrm{mM})$ and L-NAME $(0.1 \mathrm{mM})(\mathbf{\square})$. Rings from seven fetuses were studied in the absence of indomethacin and L-NAME $(\square)$. Cumulative dose-response curves for caffeine $(0.003-0.3 \mathrm{mM})$ were constructed. Net active tension is expressed as a percentage of the maximal active tension. The same findings were seen when ductus rings were exposed to either indomethacin alone (two fetuses) or L-NAME alone (two fetuses) (data not shown). Values are mean $\pm \mathrm{SD}$.

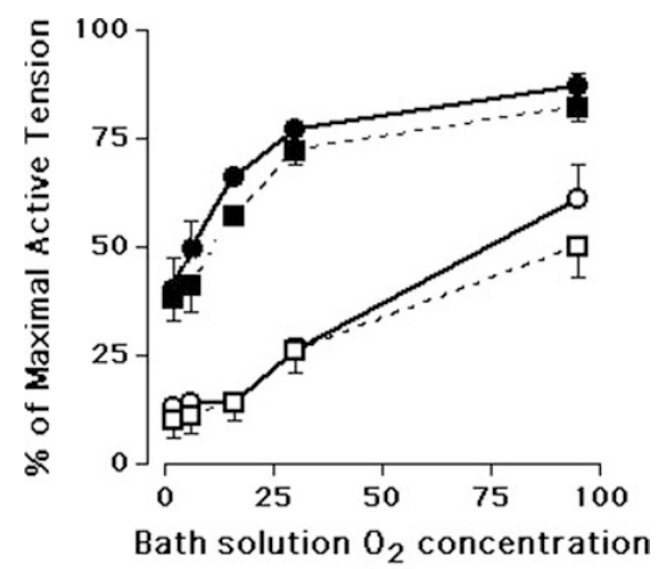

(\%)

Figure 2. Vasomotor response of fetal ductus to caffeine and oxygen. Ductus rings were incubated in modified Krebs solution, equilibrated with $15 \%$ $\mathrm{O}_{2} / 5 \% \mathrm{CO}_{2}$, containing either (a) indomethacin $(0.005 \mathrm{mM})$ plus L-NAME $(0.1 \mathrm{mM})$ (rings from five fetuses) or (b) no inhibitors (rings from seven fetuses). The rings were first sequentially exposed to $2 \%, 6 \%, 15 \%, 30 \%$, and $95 \%$, oxygen. Following the oxygen dose-response curve, the rings were returned to the initial bath conditions [either (a) with indomethacin plus L-NAME or (b) without indomethacin plus L-NAME). They were then incubated with caffeine $(0.1 \mathrm{mM})$ before another oxygen dose-response curve was performed. Values represent net active tension expressed as a percentage of the maximal active tension. Net active tension, at each oxygen concentration, was compared before and after caffeine exposure. Indomethacin + L-NAME + caffeine $(\square)$; indomethacin + L-NAME $(\bullet)$; caffeine only $(\square)$; no additions $(\bigcirc)$.

Caffeine's lack of effect was observed in both the presence and absence of indomethacin and L-NAME (Fig. 1). Similarly, caffeine had no effect on the response of the ductus to increasing oxygen concentrations (Fig. 2). At toxic concentrations of the drug $[20 \mathrm{mM}$, where cyclic nucleotide breakdown is inhibited by inactivating phosphodiesterases (21)], caffeine caused a profound $[73 \pm 7 \%(n=10)]$ reduction in active ductus tension. This was observed in both the presence and absence of indomethacin and L-NAME (data not shown).

\section{DISCUSSION}

Methyl xanthines, like caffeine, are widely used in the neonatal period to prevent apnea of prematurity. The recently reported randomized trial of Schmidt et al. (15) was primarily designed to evaluate the long-term effects of caffeine on neurodevelopmental outcome. During an analysis of secondary short-term outcomes, they found that infants in the caffeine group spent less time intubated, less time on continuous positive airway pressure, and less time in supplemental oxygen than infants in the placebo group. An unexpected finding of the study was that infants who were randomly assigned to caffeine treatment had less need for pharmacologic and/or surgical closure of a PDA.

We studied isolated rings of fetal lamb ductus arteriosus and found no evidence of a direct effect of therapeutic caffeine concentrations on ductus contractility, nor was there any effect of caffeine on the ductus' contractile response to graded increases in oxygen or to inhibition of endogenous prostaglandin and nitric oxide production. 
It is unlikely that the difference between our in vitro findings and the in vivo findings of Schmidt et al. is due to species differences; the ovine ductus does express adenosine receptors (Chandrasekar et al., Pediatric Academic Societies Meeting, May 1-4, 2004, San Francisco, CA, abstract no. 549) and is relaxed by exogenous adenosine $(10,22)$ (Clyman, unpublished observations). It is also unlikely that the decreased need for PDA treatment in vivo is due to an increase in pulmonary vascular resistance (with a subsequent decrease in ductus shunting); although caffeine contracts the pulmonary vessels at very high concentrations (25), it relaxes them at concentrations that are more likely to be achieved in vivo $(21,26)$.

The discrepancy between our in vitro findings and reported in vivo findings may be due to one of several factors: In vivo, the ductus is exposed to shear stresses that were not considered in our in vitro model; caffeine might interact with shearrelated signaling (27). Caffeine may also act at some site distant from the ductus, altering the production of circulating substances that might affect ductus contractility. It is also possible that, rather than having an effect on ductus contractility; caffeine's ability to decrease the infant's need for positive pressure ventilation may make neonatologists less concerned about the persistence of a PDA shunt and less aggressive in its treatment (Clyman and Soll, unpublished observations).

Acknowledgments. The authors acknowledge the technical help of Bao Mei Liu and Francoise Mauray in this study.

\section{REFERENCES}

1. Waleh N, Kajino H, Marrache AM, Ginzinger D, Roman C, Seidner SR, Moss TJ, Fouron JC, Vazquez-Tello A, Chemtob S, Clyman RI 2004 Prostaglandin E2mediated relaxation of the ductus arteriosus: effects of gestational age on g proteincoupled receptor expression, signaling, and vasomotor control. Circulation 110:2326-2332

2. Coceani F, Olley PM 1973 The response of the ductus arteriosus to prostaglandins. Can J Physiol Pharmacol 51:220-225

3. Keck M, Resnik E, Linden B, Anderson F, Sukovich DJ, Herron J, Cornfield DN 2005 Oxygen increases ductus arteriosus smooth muscle cytosolic calcium via release of calcium from inositol triphosphate-sensitive stores. Am J Physiol Lung Cell Mol Physiol 288:L917-L923

4. Olschewski A, Hong Z, Peterson DA, Nelson DP, Porter VA, Weir EK 2004 Opposite effects of redox status on membrane potential, cytosolic calcium, and tone in pulmonary arteries and ductus arteriosus. Am J Physiol Lung Cell Mol Physiol 286:L15-L22

5. Nakanishi T, Gu H, Hagiwara N, Momma K 1993 Mechanisms of oxygen-induced contraction of ductus arteriosus isolated from the fetal rabbit. Circ Res 72:12181228
6. Konduri GG, Gervasio CT, Theodorou AA 1993 Role of adenosine triphosphate and adenosine in oxygen-induced pulmonary vasodilation in fetal lambs. Pediatr Res 33:533-539

7. Tristani-Firouzi M, Reeve HL, Tolarova S, Weir EK, Archer SL 1996 Oxygeninduced constriction of rabbit ductus arteriosus occurs via inhibition of a 4-aminopyridine-, voltage-sensitive potassium channel. J Clin Invest 98:1959-1965

8. Coceani F, Armstrong C, Kelsey L 1989 Endothelin is a potent constrictor of the lamb ductus arteriosus. Can J Physiol Pharmacol 67:902-904

9. Clyman RI, Waleh N, Black SM, Riemer RK, Mauray F, Chen YQ 1998 Regulation of ductus arteriosus patency by nitric oxide in fetal lambs. The role of gestation, oxygen tension and vasa vasorum. Pediatr Res 43:633-644

10. Mentzer RM Jr, Ely SW, Lasley RD, Mainwaring RD, Wright EM Jr, Berne RM 1985 Hormonal role of adenosine in maintaining patency of the ductus arteriosus in fetal lambs. Ann Surg 202:223-230

11. Kajino H, Chen YQ, Seidner SR, Waleh N, Mauray F, Roman C, Chemtob S, Koch CJ, Clyman RI 2001 Factors that increase the contractile tone of the ductus arteriosus also regulate its anatomic remodeling. Am J Physiol Regul Integr Comp Physio 281:R291-R301

12. Seidner SR, Chen Y-Q, Oprysko PR, Mauray F, Tse MM, Lin E, Koch C, Clyman RI 2001 Combined prostaglandin and nitric oxide inhibition produces anatomic remodeling and closure of the ductus arteriosus in the premature newborn baboon. Pediatr Res 50:365-373

13. Clyman RI, Mauray F, Roman C, Heymann MA, Ballard PL, Rudolph AM, Payne B 1981 Effects of antenatal glucocorticoid administration on the ductus arteriosus of preterm lambs. Am J Physiol 241:H415-H420

14. Clyman RI, Mauray F, Heymann MA, Roman C 1989 Influence of increased pulmonary vascular pressures on the closure of the ductus arteriosus in newborn lambs. Pediatr Res 25:136-142

15. Schmidt B, Roberts RS, Davis P, Doyle LW, Barrington KJ, Ohlsson A, Solimano A, Tin W 2006 Caffeine therapy for apnea of prematurity. N Engl J Med 354:21122121

16. Wells JN, Kramer GL 1981 Phosphodiesterase inhibitors as tools in cyclic nucleotide research: a precautionary comment. Mol Cell Endocrinol 23:1-9

17. Blaustein MP, Golovina VA, Song H, Choate J, Lencesova L, Robinson SW, Wie WG 2002 Organization of $\mathrm{Ca} 2+$ stores in vascular smooth muscle: functional implications. Novartis Found Symp 246:125-141; discussion 221-227

18. Whorton AR, Collawn JB, Montgomery ME, Young SL, Kent RS 1985 Arachidonic acid metabolism in cultured aortic endothelial cells. Effect of cAMP and 3-isobutyl1-methylxanthine. Biochem Pharmacol 34:119-123

19. Manku MS, Horrobin DF 1976 Chloroquine, quinine, procaine, quinidine and clomipramine are prostaglandin agonists and antagonists. Prostaglandins 12:789801

20. Fredholm BB 1995 Astra Award Lecture. Adenosine, adenosine receptors and the actions of caffeine. Pharmacol Toxicol 76:93-101

21. Fredholm BB, Battig K, Holmen J, Nehlig A, Zvartau EE 1999 Actions of caffeine in the brain with special reference to factors that contribute to its widespread use. Pharmacol Rev 51:83-133

22. Clyman RI, Saugstad OD, Mauray F 1989 Reactive oxygen metabolites relax the lamb ductus arteriosus by stimulating prostaglandin production. Circ Res 64:1-8

23. Clyman RI, Mauray F, Wong L, Heymann MA, Rudolph AM 1978 The developmental response of the ductus arteriosus to oxygen. Biol Neonate 34:177-181

24. Clyman RI, Hardy P, Waleh N, Chen YQ, Mauray F, Fouron J-C, Chemtob S 1999 Cyclooxygenase-2 plays a significant role in regulating the tone of the fetal lamb ductus arteriosus. Am J Physiol 276:R913-R921

25. Janssen LJ, Lu-Chao H, Netherton S 2001 Excitation-contraction coupling in pulmonary vascular smooth muscle involves tyrosine kinase and Rho kinase. Am J Physiol Lung Cell Mol Physiol 280:L666-L674

26. Porter VA, Rhodes MT, Reeve HL, Cornfield DN 2001 Oxygen-induced fetal pulmonary vasodilation is mediated by intracellular calcium activation of $\mathrm{K}(\mathrm{Ca})$ channels. Am J Physiol Lung Cell Mol Physiol 281:L1379-L1385

27. Bostel S, Malo M, Rouzaire-Dubois B, Dubois JM 2002 Calcium and voltagedependent alterations of cell volume in neuroblastomaxglioma hybrid NG108-15 cells. Pflugers Arch 444:186-192 